\title{
Chinese Organizations in Sub-Saharan Africa: New Dynamics, New Synergies ${ }^{1}$
}

\author{
Terence Jackson, Middlesex University Business School, London, UK \\ Lynette Louw, Faculty of Commerce, Rhodes University, South Africa \\ Shuming Zhao, Nanjing University Business School, China \\ Roshan Boojihawon, Open University Business School, UK \\ Tony Fang, University of Stockholm, Sweden
}

Sub-Saharan Africa has long been neglected by international management scholars, while China has been the subject of extensive study. Up to recently the focus on China was as a large potential market for the West: management scholarship tends to follow the blue chip companies. Yet this has been changing over the last few years, to focus on China in the world, to look more closely not at international joint ventures in China, not at Western corporations working with Chinese partners in China, but at Chinese MNCs operating across international markets.

The neglect of Africa as a suitable focus of study for international management scholars has meant that the key role that China now plays in Africa, the implications for Africa's development, the relationship with Western international institutions and the huge potential impact on management scholarship itself, has largely gone unnoticed and unstudied (Jackson, Louw, \& Zhao, 2013).

Management studies unfortunately tends to trail behind the other social and behavioral sciences in terms of applying critical theory. Such an example is the recent interest in Postcolonial Theory by more critical international and cross-cultural management scholars such as Jack and Westwood (2009). This theory focuses on North-South (or West-East) relations, where globally dominant modalities are not just accepted but are also internalized by societies in the global South (inferiority of institutions, culture, organizations and management practices are assumed), and the modernizing trajectory of Western management thought and practices proceeds unabated.

Yet we no longer live in a postcolonial world. China's presence in Africa is changing all that, as is its presence in many other markets of the global South, as is India's presence in these markets. Connell (2007), for example, writes about an emerging "Southern Theory" centered on geographically non-globally dominant ideologies. The extent to which management scholars may now have to sit up and take notice of these theories in order to understand South-South interaction may be changing, as we are introduced to new geopolitical dynamics that our extant international management theories are not able to deal with: critical theories notwithstanding, as those scholars who are now playing with Postcolonial Theory, which has been around in the humanities and the social sciences for many decades, may well be focused on a period of time now gone.

So, what of the apparent accusation that China is merely the new imperialist in Africa? If this is the case, then our argument above that new South-South dynamics are coming to the fore is clearly false. This accusation is also combined with an assumption that we cannot lump China under the "global South" heading. We will deal with the latter first.

\section{The emerging global South}

In political science and international relations the concept of a global North-South divide, which arose after WWII, was consolidated in what has been referred to as the Brandt Line, conceptualized by the former West German Chancellor Willy Brandt in 1980 as an imaginary line delineating the boundary between the industrial North and the poorer South, a political geography that had mostly eclipsed the divide between East and West. With countries such as China and India, which were placed at the South of this divide, Lees (2011) argues that despite considerable growth in the economies of both these countries, the concept of a North-South divide is still relevant today when considering both economic inequalities within nation states and political and military inequalities in international relations. Connell's (2007: 212) concept of an emerging Southern Theory in social science is also premised on the persisting relevance of this conceptual global divide, which she says constitutes an expression of "the long-lasting pattern of inequality in power, wealth and cultural influence that grew historically out of European and North American imperialism." That China and India are emerging as major geopolitical and geo-economic players is not a reason to deny historical circumstance and reclassify them as "Northern" states.

\section{A new imperialism?}

To assess the claim that China is the new imperialist in Africa, it is necessary to first look at the West's history of involvement in Africa, which is quite different to that of China. 
It could be argued that the motives for Western colonialism, the need to subjugate periphery countries, the motive to impose a "civilizing" religion and more recently the neo-colonial motives to impose a Western liberal democratic governance structure and universal human rights all add up to a pejorative portrayal of local knowledge and values that appears reflected in the modernizing project in management and organization.

Modernization Theory in its various guises has over the last decades underpinned the West's policies on international development. This has be-

come largely institutionalized through the prominence of economists from the "Chicago School" (emanating from Milton Friedman and his neo-liberal philosophy) in the IMF and World Bank. Aid from these two organizations has been conditional on the countries' governments implementing structural adjustment programmes that required them to restructure their economies and societies in line with neo-liberal theory (Ritzer, 2011). This has of course included many African countries. This theory of development became known as the "Washington Consensus" because it was so closely linked to the economic and political position of the US, as well as the location of these supranational organizations in the US's capitol. This Consensus has been underpinned by a view that "unimpeded private market forces were seen as the driving engines of growth" (Cavanagh \& Broad, 2007: 1243), and an absence of "any concern for equity, redistribution, social issues, and the environment" (Ritzer, 2011: 39).

Conditionality has been fundamental to Western countries' development programmes in Africa, hence their concern with China's apparent different approach. Campbell (2008: 92-93) reports a spokesperson of the World Bank and IMF saying that China has "undermined years of painstaking efforts to arrange conditional debt relief," and that the then head of the World Bank Paul Wolfowitz argued that "China would weaken the hold of the IMF and World Bank over Africa and accused it of fostering corruption," going on to report that "this was before the head of the World Bank was himself removed because of corruption."

Western involvement in Africa can be traced back further than colonial times, to the ultimate "human resource" project: the transatlantic slave trade. China's engagement with Africa can be traced back to trade during the Han dynasty (206BC-220AD), and the 1950s and 1960s in modern times. This appears qualitatively different from European involvement in the wake of the slave trade. Following the China-Russia split in 1956, much of the anti-colonial struggles in the Third World had ideologically allied themselves with China, as a result of its "apparently disinterested substantive support to liberation movements or hardpressed front line ... states, particularly in Mozambique, South Africa, Southwest Africa, Zambia and Zimbabwe, its populist orientation towards the peasantry and the need for an agrarian revolution, towards struggle from below, and its emphasis on guerrilla warfare and armed struggle against imperialism" (Young, 2001: 188). Its role in the decolonization of Africa was therefore significant.
Unlike the trajectory of the Western modernizing project, which informs much of the management literature on Africa, underpinned by centuries of colonialism, and critiqued among others by Postcolonial Theory, the coming to Africa of China has been quite different. One could logically expect the outcomes of Chinese organizations in Africa also to be different. In addition, the way this relationship and these dynamics are

\section{China's motive in Africa}

Certainly China's motive has been commerce rather than stressing a need for Africa's political and economic reform (Mohan \& Power, 2008) in contradistinction to the West that sought to introduce a neoliberal ideal (Carrier \& Miller, 1998). It appears not to have been a "civilizing" nor a proselytizing motive. Yet there has been an emerging line within the international relations literature that alludes to a nationalist perspective and a Chinese perception of superiority of Chinese culture: that it is the patriotic duty of China's elites to spread Chinese values and culture around the world (Nyiri, 2006; Callahan, 2008). This may well manifest itself in the funded Confucius Institutes attached to a number of the continent's universities.

However, support for the contention that there is a lack of a "civilizing" or modernizing mission appears to manifest itself in China's apparent disregard for governance and human rights issues in countries such as Sudan and Zimbabwe. Marafa (2007) also alludes to there not appearing to be a disparaging attitude towards African cultures in China's engagement. Despite also the large numbers of Chinese immigrants in Africa, Brautigam (2011) finds no empirical evidence of a "land-grab" that would indicate a colonizing intention.

Modernization Theory, which as mentioned appears firmly embedded in much international management scholarship, is firmly entrenched in a belief in the benefits of the spread of global capitalism in modernization, whereas China's professed policies have been founded in a Marxist-Leninist-Moaist tradition that has been fundamentally anti-capitalist and anti-colonialist (Thiam \& Mulira, 1999; Young, 2001).

The first author of the current article has already been accused, in a recent submission to a scholarly management journal, of being too proChinese. Yet the purpose of the above potted history lesson is to offer the perspective that international management scholars need to begin any analysis of Chinese management and organizations in Africa by at- 
tempting to understand the motives for the Chinese being there, and not assuming it has the same motivations as the West.

Its current-day motives for being in Africa, which Gill, Huang and Morrison (2007) describe as resources-seeking to fuel China's development goals, market-seeking to sustain its growing economy and politicalseeking to support its aspirations to be a global influence, must be seen within this recent historical context. It may also be possible that Gill et al.'s (2007) three types of motives may be too restrictive in terms of hypothesizing the connection between the reasons for China's being in Africa and the approach that Chinese MNEs have towards people policies and practices. Also there may not be a direct relationship between wider strategic motives professed by Chinese government policies and their manifestations in inter-governmental relations with African governments and actions at organizational level, as we discuss below. Yet just as the way that the West's resource-seeking motives for being in Africa may have been modified by a civilizing and proselytizing ethos, so China's resource-seeking motive may be moderated by the nature of its socio-political engagement.

This appears different from the socio-political interventionist development programs of the West premised on the civilizing missions of previous centuries. Rather, according to Nyiri (2006: 104) it involves concepts of modernization and productivity together with community harmony, which are demonstrated by, for example, entrepreneurial success, rather than "educating or'reforming' natives."

\section{What do Chinese organizations bring to Africa?}

China's motives have got to be considered in association with how wider geopolitical relationships are conceptualized and how these are changing. What Chinese organizations bring with them to African countries are a function of such motivations and rationales discussed above, but also a product of previous and current geopolitical relations. The way people are managed in China is a product of such relationships. Of these principles and practices, what is then brought to Africa is another such product. Whether or not Chinese managers come to Africa to impose, instruct, teach or learn is yet another product of geopolitical relations both historic and current.

Through the Western literature, we know a lot about Chinese management in China, yet we know so little about what happens when Chinese firms go abroad, and even less about what Chinese firms take to Africa, and the synergies between Chinese management philosophies and practices and their African partners, staffs and communities. Notably, the literature on management in Africa has long decried the lack of appropriateness of Western organizations in Africa (Jackson, 2004). Are Chinese approaches any more appropriate to the local contexts?

In China there is a tradition of absorbing foreign influences, but with Chinese characteristics. Even though companies have been adopting apparent Western HRM practices such as linking performance with pay, the reward system is still by and large based on equality, with employ- ees exerting extensive control over the distribution of pay, with income inequality still being seen as potentially disruptive to group harmony and social adhesion (Cooke, 2004). Indeed, Warner (2010) asserts a much bigger emphasis in today's China on harmony and Confucian values, and a turning away from simply economic efficiency. On the face of it there seems a potential synergy between the humanistic values of Confucianism, and perhaps Buddhism, and the African humanistic values of ubuntu.

The concept of ubuntu management was popularized in the late 1990s in South Africa by, among others, Mbigi (1997) and experimented with in some of the larger corporations and public enterprises, amidst a focus on empowerment and employment equity (Jackson, 1999). This represented an emphasis on the humanity of people working in organizations, and a move away from seeing people as resources in an instrumental (Western) perspective. This embodies a view that African communities' values may be different from the Western focus on the individual and what he or she achieves. It views people as having an intrinsic value, a value in their own right, for who they are as part of a collective (Jackson, 2002).

The possible synergies between Chinese and African approaches still need to be explored through empirical research (a task that is underway by the present research group). For the time being we can examine what we currently know about how Chinese firms (with the recognition that these may be from diverse sectors, state-owned and private, large and small) operate in Africa. There are indications that there may be a disjuncture between strategic intent and actual firm operations.

\section{A strategic-operational split}

Jackson (in press), drawing on the sparse empirical research already undertaken (most notably a study by the African Labor Research Network: Baah \& Jauch, 2009), concludes that although at governmental levels there are many projects to enhance human capacity, such as teacher training, funded by China, and that community development as well as huge infrastructure projects are contributing to Africa's development, at the individual organization level, Chinese firms are definitely contributing to employment in a situation where the failure of African markets to create jobs in the formal economy has led to an excess of labor. For example Africa Monitor (2010: 7) reports in Zambia that because of China's policy of diversification from the extraction industries towards manufacturing, infrastructure and agriculture, "FDI pledges in the other three sectors are substantial at around US\$625mn combined, and are directly responsible for the creation of around 13,000 jobs." Brautigam (2011) points out that it simply is not true that China takes its entire workforce from China. Yet the working conditions and salaries are often not good (although often on a par with local firms, yet often worse than Western firms).

It does seem that many Chinese firms do take their managerial and skilled technical staff to Africa, with less skilled or unskilled jobs given to locals. Yet there is little evidence of upskilling of local staff. 
Much of the interaction of Chinese staff with local communities at the firm level appears to remain with recruiting local staff. Strategically it appears that China is engaging with the needs of African communities in providing important infrastructure, contributing to agricultural projects in response to needs filtered through government. Yet there is lack of research on Chinese MNEs' direct engagement with local communities. It is unlikely from the available evidence that there is any deliberate attempt of Chinese managers to engage directly other than for recruitment. Chinese expatriates tend to live in compounds in a frugal way and appear not to have much connection with the local community (Brautigam, 2011).

So while at strategic policy levels there are intentions and projects addressed toward friendship, mutual cooperation, community and human capacity development, this appears not to be directly translated to what state-owned and private organizations do, and how they operate.

\section{Mutual learning}

Mutual learning may also be a contentious issue. While the strategic intent may be there, the African Labour Research Network study reports that "Unions identified language barrier as one of the factors hampering smooth labour relations in Chinese companies. Chinese managers find it difficult to communicate in English, which is the official language in all the countries where the study was conducted" (Baah \& Jauch, 2009: 74).

If language is an issue among Chinese expatriates in Africa, then it is not too far a stretch of the imagination to ponder that if cultural synergies do exist between Chinese and African approaches, it may be the case that neither the Chinese nor the Africa partners know this or understand how this may be utilized to benefit the relationship between the two. This is an area ripe for research, and for future management development.

\section{Future research}

China's engagement in Africa has not sufficiently captured the attention of international management scholars. This is certainly not the case for Western governments and the Western press. The former appear challenged by China's presence, and the latter appear entranced by the very newsworthy and negative snippets that can be extracted. It is often these negative connotations that influence perception in management studies where Modernization Theory is so entrenched and has provided either an aversion to studying sub-Saharan Africa, or provides this study with such a negative inflection that it is difficult to identify it as scientific research. While China in Africa may generate in time more interest from international management scholars, there is a danger that these pejorative perceptions may not provide a balanced view from those pursuing a modernization perspective, and that the full implications of a changing geopolitical dynamics may not be realized by the more critical scholars still trying to work within postcolonial dynamics. The premise that geopolitics (such as the dominance of the United States economy after WWII and the rise of management studies as an area of academic study) has major implications for knowledge and the transfer globally of that knowledge, is the starting point of the project currently funded by Sandisa Embewu at Rhodes University, and led by the authors of the current article. We are in the process of investigating those and other issues outlined above. We hope that this work will encourage other management scholars to follow suit, and indeed that they will contact us if they wish to become involved.

\section{References}

Africa Monitor. 2012. China: future partnership. Africa Monitor: Southern Africa, 17(1): 12.

Baah, A. Y., \& Jauch, H. (Eds) 2009. Chinese Investments in Africa: A Labour Perspective. Johannesburg: African Labour Research Network.

Bräutigam, D. 2011. The Dragon's Gift: The Real Story of China in Africa. Oxford: Oxford University Press.

Callahan, W. A. 2008. Chinese Visions of World Order: Post-hegemonic or a New Hegemony? International Studies Review, 10: 749-761.

Campbell, H. 2008. China in Africa: Challenging US global hegemony. Third World Quarterly, 29(1): 89-105.

Carrier, J. \& Miller, D. E. 1998. Virtualism: A New Political Economy. Oxford: Berg.

Cavanagh, J., \& Broad, R. 2007. Washington Consensus. In J. A. Scholte \& R. Robertson (Eds), Encyclopaedia of Globalization. New York: MTM Publishing.

Connell, R. 2007. Southern Theory. Cambridge: Polity.

Cooke, F. L. 2011. Employment relations in China and India. In M. Barry \& A. Wilkinson (Eds), Research Handbook of Comparative Employment Relations: 184-213. Cheltenham: Edward Elgar.

Gill, B., Huang, C-H., \& Morrison, J. S. 2007. Assessing China's Growing Influence in Africa. China Security, 3(3): 3-21.

Jack, G., \&Westwood, R. 2009. International and Cross-cultural Management Studies: A Postcolonial Reading. Basingstoke: Palgrave Macmillan.

Jackson, T. 1999. Managing Change in South Africa: Developing People and Organizations. International Journal of Human Resource Management, 10(2): 306-326.

Jackson, T. 2002. The management of people across cultures: Valuing people differently. Human Resource Management, 41(4): 455-475.

Jackson, T. 2004. Management and Change in Africa: A Cross-cultural Perspective. London: Routledge.

Jackson, T., Louw, L., \& Zhao, S. M. 2013. China in Sub-Saharan Africa: Implications for HRM Policy and Practice at Organizational Level. International Journal of Human Resource Management, 2512-2533. 
Jackson, T. In Press. Employment in Chinese MNEs: Appraising the Dragon's Gift to sub-Saharan Africa. Human Resource Management.

Lees, N. 2011. The Dimensions of the Divide: Theorising Inequality and the Brandt Line in International Relations. Paper presented as part of the Panel'South-South Cooperation: History, Concepts, Trends'at the IPSA-ECPR Joint Conference 'Whatever Happened to NorthSouth?', Sao Paulo 201, online at http://saopaulo2011.ipsa.org/ sites/default/files/papers/paper-817.pdf, accessed 19 July 2012.

Marafa, L. M. 2007. Africa's Business and Development Relationship with China: Seeking Moral and Capital Values of the Last Economic Frontier. Paper presented at the African Economic Conference, November $15^{\text {th }}-17^{\text {th }} 2007$ UN Conference Centre, Addis Ababa, Ethiopia.

Mbigi, L. 1997. Ubuntu: The African Dream in Management. Randburg, S. Africa: Knowledge Resources.

Mohan, G., \& Power, M. 2008. New African choices? The politics of Chinese engagement. Review of African Political Economy, 115: 23-42.

Terence Jackson is Professor of Cross-cultural Management at Middlesex University Business School, London. He has published extensively on management in Africa and on cross-cultural management in journals including Journal of Management Studies, Human Relations, Human Resource Management, Journal of World Business, Organization, International Journal of Human Resource Management and Management International Review. He has written eight books including Management and Change in Africa: A Cross-cultural Perspective (Routledge: 2004), the result of a 15-country collaborative study of sub-Saharan Africa. He is editorin-chief of International Journal of Cross Cultural Management (Sage). His particular interest is in the synergies between Chinese and African approaches, as well as the wider implications of China's international engagement for theory building. t.jackson@mdx.ac.uk

Lynette Louw is Raymond Ackerman Chair of Management, Department of Management, and deputy dean, Faculty of Commerce, Rhodes University, South Africa. She is a visiting scholar at universities in Germany, Netherlands and China. Her areas of speciality include strategic management and Cross-cultural management. She is on the editorial board of a number of national and international journals and has co-author several books and book chapters focused on management in Africa, and numerous academic articles. She is leading the Sandisa Embewu funded project 'Chinese Organizations in Sub-Saharan Africa: New Dynamics, New Synergies', and has a particular interest in Afrocentric approaches to management. I.louw@ru.ac.za.

Shuming Zhao is Nanjing University Chair Professor and Honorary Dean of the School of Business, Nanjing University, the People's Republic of China. As an internationally-known scholar in human resource management and multinational business management he has published more than 20 books and over 300 academic papers and article and has received an honorary doctoral degree from Seton Hill University in the United States in 2006 and the Chancellor's Medallion from the Univer-
Nyiri, P. 2006. The yellow man's burden: Chinese migrants on a civilizing mission. The China Journal, 56: 83-106.

Pakenham, T. 1991/2001. The Scramble for Africa. London: Phoenix Press.

Ritzer, G. 2011. Globalization: The Essentials. Oxford: Wiley-Blackwell.

Thiam, I. D., \& Mulira, J. 1999. Africa and the socialist countries. In A. A. Mazrui (Ed.), General History of Africa, Vol. VIII Africa Since 1935. Paris: Unesco/Oxford.

Warner, M. 2010. In search of Confucian HRM: Theory and practice in Greater China and beyond. International Journal of Human Resource Management, 21(12): 2053-2078.

Young, J. C. 2001. Postcolonialism: An Historical Introduction. Malden, CA: Blackwell.

\section{Endnote}

1 This article arises from an international collaborative project of the same title, currently generously funded by the Sandisa Embewu Fund of Rhodes University, South Africa.

sity of Missouri-St. Louis in 2008. He has chaired several research projects for the National Natural Science Foundation of China and received a number of prestigious prizes and awards for his research in China and internationally. He is particularly interested in the human resource aspects of China in Africa. zhaosm@nju.edu.cn.

Dev K. (Roshan) Boojihawon is Lecturer in Strategy at the Open University Business School, UK. He is currently leading an international project on 'Strategy processes, practices \& learning in sub-Saharan Africa' and recently co-edited a book on organisational collaborations. His academic writings have appeared as several open and distance learning materials on strategy and international management, book chapters, conferences papers and peer-reviewed articles published in such journals as International Business Review, Services Industries Journal, African journal of Business \& Economic Research and African Journal of Economic and Management Research. He is particularly interested in the strategic aspects of Chinese firms in Africa, with a special interest in Mauritius. Roshan.Boojihawon@open.ac.uk.

Tony Fang is Professor of Business Administration at the School of Business Stockholm University. He is an internationally respected researcher in cross-cultural management and Chinese business studies, and has authored a number of the books, book chapters and peer-reviewed articles published in such journals as Asia Pacific Journal of Management, International Business Review, International Journal of Cross Cultural Management, International Journal of Intercultural Relations, International Studies of Management \& Organization, Journal of Business and Industrial Marketing, Journal of Business Ethics, Journal of World Business, Management and Organization Review, Organizational Dynamics, and Scandinavian Journal of Management. He is co-editor of International Journal of Cross Cultural Management. He is particularly interested in ChineseAfrican negotiation.tf@fek.su.se. 